\title{
Dampak Kebijakan Pembangunan Pariwisata Pantai Terhadap Apsek Sosial, Ekonomi, Dan Perilaku Masyarakat
}

\author{
I Dewa Nyoman Juniasa \\ Sekolah Tinggi Ilmu Sosial Politik Wira Bhakti Denpasar, Bali, Indonesia \\ Email: dewajunibali@gmail.com
}

\begin{abstract}
ABSTRAK
Diinvestigasi mengguanakan metode kualitatif, penelitian ini mengkaji dampak pengembangan obyek wisata terhadap aspek sosial, ekonomi, dan prilaku masyarakat di Denpasar, Bali, Indonesia. Hasil penelitian menunjukkan bahwa 1) dalam konteks social, muncul keramaian dan kesenjangan sosial di tengah masyarakat; 2) dalam konteks ekonomi, berbagai macam usaha pendanaan lahir seperti usaha mandiri, modal lembaga BUMDES, dan perubahan pelaku usaha; dan 3) dalam hal perubahan perilaku, para pelaku usaha non lokal dalam sektor pendidikan dan kesehatan mengalami perubahan yang signifikan. Secara spesifik, temuan penelitian ini menunjukkan bahwa dampak sosial yang ditimbulkan meliputi perubahan kondisi wilayah menjadi ramai, adanya alih fungsi lahan. Dampak ekonomi, masyarakat dapat memilik usaha mandiri. Dampak prilaku yang ditimbulkan yaitu respon baik pelaku wisata lokal terhadap non lokal yang saling melengkapi. Di samping itu, penelitian ini juga menemukan fakta bahwa kebijakan pengembangan obyek wisata dilakukan dengan perencanaan yang baik oleh masyarakat desa bersama pemerintah daerah yang tujuan utamanya mewujudkan kesejahteraan masyarakat.
\end{abstract}

Kata Kunci: Kebijakan pariwisata pantai, perilaku, ekonomi, social, masyarakat

\section{INTRODUCTION}

Seiring perkembangan pariwisata yang semakin meningkat, pada tahun 1957 dibangunlah hotel pertama di Desa Sanur dengan nama Hotel Sindhu Beach, disusul pembangunan Hotel Bali Beach yang mulai beroparasi pada tahun 1966 . Meskipun wisata bahari belum dikenal saat itu, di Sanur sudah terbentuk suatu proyek pengembangan Sanur yang disebut Beach Market pada tahun 1971. Beach Market tersebut menyajikan jasa pelayaran dengan jukung yaitu perahu- perahu tradisional, pameran patung-patung, lukisan, pertunjukan tari- tarian dan pengelolaan kafe dan restoran. Saat ini masyarakat sudah semakin kritis, sehingga semakin peduli terhadap kebijakan yang berpengaruh terhadap kehidupaan pribadinya, sehingga pemerintah harus semakin responsif dan akomodatif (Winarno, 2014). Setiap kebijakan pemerinah diupayakan bermanfaat untuk kesejahteraan, keadilan dan kemandirian. Walaupun masyarakat meliputi kebinekaan, 
keanekaragaman kepentingan serta kemampuan, namun kebijaan publik harus dapat memenuhi kebutuhan, aspirasi masyarakat luas dan optimal (Adisasmita R.2015: 13). Dampak kebijakan adalah keseluruhan efek yang ditimbulkan oleh suatu kebijakan dalam kondisi kehidupan nyata (Dye, 1981).

Menurut Anderson (1984) semua bentuk manfaat dan biaya kebijakan, baik yang langsung maupun yang akan datang, harus diukur dalam bentuk efek simbolis atau efek nyata. Output kebijakan adalah berbagai hal yang dilakukan oleh pemerintah. Seperti pengembangan obyek wisata pantai Mertasari, merupakan wisata bahari yang baru dikembangkan. Lokasi di wilayah Desa Sanur Kauh tergolong memiliki tanah yang tidak produktif seperti rawa-rawa. Desa Sanur kauh memiliki iklim laut Tropis yang dipengaruhi oleh angin musim dan terdapat musim kemarau dan musim hujan yang diselingi dengan musim pancaroba. Jumlah penduduk akhir Desember berjumlah 8.076 jiwa dan 2013 KK. Pantai Sanur mulai dikenal kemasyurannya di dunia internasional sejak Lemayeur, pelukis asal Belgia yang datang ke sanur tahun 1932 memperkenalkan kawasan ini melalui lukisan (BLH, 2016). Desa Sanur Kauh memiliki hutan mangrove sebanyak 7,0 Ha di sepanjang garis pantai yang dipengaruhi pasang surut air laut yaitu sepanjang pantai Pengembak yang di kenal pantai Mertasari. Destinasi wisata Pantai Mertasari, menjadikan fungsi wilayah ini menjadi lebih menjanjikan, prospek ke depan dapat menambah peluang kerja, pengembangan potensi pertumbuhan ekonomi Denpasar selatan dan Bali pada umumnya. Mata pencaharian masyarakat paling banyak sebagai buruh/ swasta 3.651 jiwa, 600 pengerajin, dan pedagang sebanyak 422 jiwa. Mereka sebelumnya bekerja serabutan, buruh, nelayan, petani dan pedagang (Profile Desa Sanur, 2015). Kawasan Sanur sangat populer sebagai daerah tujuan wisata internasional dengan pantai berpasir putih berkualitas tinggi. Matahari terbit (sunrise) dengan siluet gunung Agung menambah panorama dan suasana pantai yang damai dan tenang untuk menikmati liburan. Berdasarkan uraian di atas, peneliti tertarik menulis dengan judul “Dampak Kebijakan Pengembangan Obyek Wisata Pantai Mertasari terhadap perubahan sosial, ekonomi dan prilaku masyarakat Desa Sanur Kauh Kecamatan Denpasar Selatan Kota Denpasar".

\section{METHOD}

Penelitian ini dilakukan di Pantai Mertasari desa Sanur Kauh Denpasar Selatan dari bulan Desember 2016 sampai Februari 2016. Penelitian ini merupakan sebuah studi kebijakan publik pengembangan obyek wisata pantai Mertasari, dari aspek dampak pengembangan obyek wisata dan sosial ekonomi serta prilaku masyarakat. Metode yang digunakan metode kualitatif (Sugiyono, 2012). Dalam penelitian ini akan dicari dampak kebijakan terhadap sosial ekonomi dan prilaku masyarakat dalam pengembangan wisata pantai Merta Sari. 


\section{RESULTS}

Obyek wisata Pantai Sanur merupakan salah satu obyek wisata pantai yang menjadi tujuan para wisatawan yang datang ke Pulau Bali selain pantai kuta. Kebijakan pengembangan wisata pantai Mertasari berdasarkan UU No. 32 tahun 2004 tentang otonomi daerah yang dilaksanakan melalui kebijakan nasional PP No.50 tahun 2011 tentang RIPARNAS tahun 2010-2025, kemudian dilanjutkan dengan kebijakan provinsi Bali dengan Perda No.16 tahun 2009 tentang RTRW provinsi 2009-2029. Selanjutnya dilaksana -kan dengan Perda Kota Denpasar No. 27 Tahun 2011 tentang RTRW Kota Denpasar tahun 2011-2031 yaitu pasal 47 ayat 3 tentang kawasan pantai Merta Sari.

Dampak kebijakan pengembangan terhadap kehidupan sosial masyarakat desa Sanur:

1. Dampak keramaian: Pantai Merta Sari pada awalnya merupakan kawasan yang ditumbuhi semak belukar yang jarang dikunjungi oleh wisatawan dibanding pantai lain (Made Ada, 2017). Usaha-usaha pedagang yang di bangun di koordinir dengan sebuah wadah yang bernama BUMDES, Namun dengan adanya pengembangan obyek wisata kondisi tersebut berubah menjadi kawasan yang sangat ramai dikunjungi wisatawan

2. Lingkungan: Dengan dikembangkannya mulai tahun 2014, infrastruktur mulai di bangun, seperti penataan pedagang, tempat parkir luas, jalan yang dibenahi, penataan tanaman pelindung disekitar pantai untuk pembangunan fasilitas penunjang pantai Merta Sari.

3. Kesenjangan sosial: Terjadinya perubahan aktifitas masyarakat dari bertani ke pariwisata dengan menekuni pekerja baru dibidang pariwisata jiwa kebersamaannya mulai memudar dan justru muncul kompetisi diantara mereka karena terjadi penurunan penghasilan akibat relokasi tempat usaha.

Dampak kebijakan pengembangan terhadap ekonomi masyarakat di desa Sanur:

1. Usaha mandiri

Dengan adanya pengembangan obyek wisata di desanya, sebagian dari mereka memiliki berbagai usaha mandiri seperti warung makan, permainan cano, penyewaan plampung, wind surfing, kite suring, snowkling. Wisata mancing, massage, dan sebagainya yang dianggap lebih menjanjikan karena dapat menghasilkan setip hari.

2. Modal BUMDES

Perokonomian masyarakat desa Sanur, khususnya di sektor pariwisata sangat terbantu dengan adanya BUMDES. Dimana mereka dapat pinjaman modal dari desa adat 14juta/bulan dengan suku bunga terjangkau untuk usaha kecil melayani berbagai kebutuhan wisatawan yang datang ke pantai Mertasari.

3. Pendapatan Pelaku Usaha 
Pendapatan pelaku usaha di pantai Mertasari sudah lebih baik dari sebelumnya, disamping mereka dapat mengangsur kewajibannya di desa adat juga dapat menyisihkan untuk ditabung serta penghasilan yang didapat Rp.800.000/hari dapat digunakan untuk menyekolahkan anak.

Dampak kebijakan pengembangan terhadap perubahan prilaku masyarakat desa Sanur

1. Respon pelaku pariwisata lokal

Respon masyarakat lokal terhadap pelaku non lokal cukup baik mengingat diantara mereka saling membutuhkan seperti para pedagang makan mendapat suplai bahan mentah pedagang dari luar desa Sanur.

2. Pendididkan: Dengan perkembangan pariwisata berimplikasi positif terhadap pendidikan masyarakat, dimana dengan semakin banyaknya wisatawan asing yang berkunjung serta pengasilan yang meningkat dapat dimanfaatkan untuk menyekolahkan anak-anak mereka serta mendorong keinginan masyarakat untuk belajar berbagai bahasa asing guna memudahkan mereka untuk berkomunikasi dengan wisatawan.

3. Kesehatan: Penghasilan yang didapatkan masyarakat dari hasil usaha pariwisata dapat meningkatkan perhatian mereka dibidang kesehatan seperti tersedianya toilet dimasing-masing rumah mereka dan menambah kesadaran mereka untuk ikut dalam berbagai program kesehatan yang diluncurkan oleh pemerintah.

\section{DISCUSSION}

\section{Dampak sosial}

\section{Keramaian}

Dampak pariwisata menimbulkan keramaian yang berasal dari wisatawan lokal maupun manca negara yang dimanfaatkan oleh masyarakat lokal untuk melakukan usaha di kawasan wisata untuk mewujudkan tujuan wisata mensejahterakan masyarakat. Dampak pariwisata terhadap kesempatan kerja bagi tenaga kerja menimbulkan hal-hal baru bagi masyarakat. Sebagaimana hasil penelitian Anggraini (2014) Kondisi Sosial Masyarakat Disekitarnya seperti, dampak sosial, kondisi lingkungan, kesenjangan sosial, ekonomi, alih fungsi bangunan, dan perbaikan berbagai infrastruktur.

\section{Lingkungan}

Pariwisata sebagai suatu kegiatan secara langsung menyentuh dan melibatkan masyarakat, sehingga timbul dampak terhadap masyarakat setempat seperti pertambahan penduduk, penataan bangunan seperti pembangunan hotel, restaurant, penginapan, pembuatan jalan menuju wisata pantai Mertasari. Dampak lingkungan 
seperti polusi asap kendaraan, debu jalan raya, kemacetan lalulintas, berkurangnya pepohonan hijau.

\section{Kesenjangan social}

Pengembangan obyek wisata pantai Mertasari menimbulkan dampak kesenjangan sosial antara pelaku wisata dan lingkungan sekitar. Penghasilan para pengusaha yang satu dengan yang lainnya terdapat perbedaan. Persaingan yang diakibatkan perbedaan penghasilan menimbulkan ego masyarakat menjadi tinggi. Keadaan ini cepat diantisipasi oleh pengelola dengan mengatur melalui zona-zona tertentu.

\section{Dampak ekonomi}

\section{Usaha Mandiri}

Ditinjau dari segi ekonomi masyarakat desa Sanur, mendapatkan lapangan kerja baru yang mereka lakukan untuk mendapatkan kesejahteraan. Keberhasilan masyarakat membuka berbagai usaha baru dengan modal usaha lewat bantuan pengelola BUMDES yang dimiliki oleh desa adat.

\section{Modal BUMDES}

Desa Adat ikut ambil bagian dalam pengelolaan dan pengembangan wisata Mertasari dengan memberikan bantuan modal kredit kepada pelaku usaha di pantai Mertasari. Kemampuan masyarakat dalam menyerap bantuan dari desa menguntungkan bagi desa adat, masyarakat dan pemerintah. Disamping itu juga untuk menghindari terjadinya kebocoran ekonomi di kawasan wisata pantai Mertasari.

\section{Pendapatan Pelaku Usaha}

Pendapatan pelaku usaha di pantai Merta Sari sudah lebih baik karena setiap hari, mendapat uang berbeda saat menjadi petani atau nelayan, penghasilan yang tidak tentu. Penghasilan yang mereka dapatkan digunakan untuk keperluan hidup dan mereka tabung/didepositokan di LPD. Pengembangan wisata membuka lapangan kerja baru dan bahkan memberikan penghasilan yang lebih baik.

Menurut Mill dalam“The Tourism, International Business” (2000, p. 168-169), menyatakan bahwa: "pariwisata dapat memberikan keuntungan bagi wisatawan maupun komunitas tuan rumah dan dapat menaikkan taraf hidup melalui keuntungan secara ekonomi yang dibawa ke kawasan tersebut"

\section{Dampak prilaku}

Respon Pelaku Wisata Lokal Terhadap Pelaku Non Lokal

Respon masyarakat lokal terhadap non lokal cukup baik dikarenakan saling mendukung dan saling menguntungkan atau/simbiosis mutualisme. Pelaku 
pariwisata non lokal sebagai penyuplai barang dan sebagai pelengkap bagi usaha yang tidak ada bagi pelaku usaha pariwisata lokal. Dalam hal ini terjadi interaksi dan komunikasi antara pelaku lokal dan non lokal saling percaya sebagai partner dalam berusaha atau berbisnis.

\section{Pendididikan}

Peningkatan perekonomian masyarakat maka membiayai pendidikan keluarganya semakin terbuka. Sebagaimana yang dikemukakan oleh Wahyudi, (2014: 77) menyatakan bahwa: "Karakteristik sosial-ekonomi seperti tingkat pendidikan, umur, kekosmopolitan dan tingkat kemampuan ekonomi mempengaruhi masyarakat desa dalam menanggapi ida atau informasi terhadap sesuatu hal'. Pendidikan akan dicari oleh masyarakat yang ekonominya sudah meningkat sehingga dengan adanya pariwisata keinginan untuk meningkatkan penddidikan menjadi lebih memungkinkan bagi masyarakat yang pola hidupnya sudah berubah ke lebih modern.

\section{Kesehatan}

Kegiatan pariwisata yang ditekuni masyarakat secara tidak langsung mengubah ekonomi masyarakat menjadi lebih baik, sehingga perhatian terhadap kesehatan mereka menjadi lebih baik. Prilaku hidup sehat yang dilakukan oleh masyarakat merupakan proses perubahan prilaku yang didukung dengan faktor sosial ekonomi masyarakat yang semakin meningkat.

\section{CONCLUSION}

Kebijakan pengembangan obyek wisata pantai Mertasari dilakukan secara baik dan terencana yang memprioritaskan masyarakat local dan masyarakat desa Sanur Kauh pada umumnya yang didukung pemerintah daerah untuk mewujudkan kesejahteraan masyarakat. Dampak sosial terhadap masyarakat adalah perubahan kondisi wilayah yang tadinya sepi menjadi ramai yang menyebabkan perubahan sosial masyarakat, perubahan lingkungan sosial. Dampak ekonomi masyarakat yang timbul adalah masyarakat memiliki kemampuan untuk usaha mandiri dengan bantuan dari BUMDES sehingga kebocoran ekonomi dapat dihindari. Dampak prilaku masyarakat yang ditimbulkan adalah respon pelaku wisata lokal terhadap pelaku non lokal terjalin baik yang saling melengkapi dan saling menguntungkan. 


\section{REFERENCES}

Adisasmita, Raharjo, 2015. Analisis Kebijakan Publik, Yogyakarta: Graha Ilmu.

BPS Kabupaten, 2012. Kecamatan Denpasar Angka, Denpasar: Kota Denpasar: www.unud.litian.pdf download: Jumat, 13:51, 31 April 2015

Pendit, N.S., 1999. Ilmu Pariwisata "Sebuah Pengantar Perdana" Jakarta: PT. Pradana Paramita.--.

Kusmayadi dan Endar Sugiatro. Metodologi Penelitian Dalam Bidang Kepariwisataan. Jakarta. PT. Gramedia Pustaka Utama. 2000.

Martini, Nina Aryani, Farida, Ida, 2011. Psikologi Perpustakaan, Jakarta: Penerbit Universitas Terbuka

Notoatmodjo, Soekidjo, 2007, Promosi Kesehatan E Ilmu Perilaku, Jakarta;Rineka Cipta

Sugiyono, 2012. Metode Penelitian Kuantitatif Kualitatif dan RED, Bandung: Alpabeta

Soebiyanto FX. 1998. Peranan kelompok dalam mengembangkan kemandirian petani dan ketanguhan berusaha tani. [disertasi]. Bogor [ID] : Institut Pertanian Bogor.

Wahyudi, Ferdi Tri, 2014, Dampak Pengembangan Pariwisata terhadap Tingkat Kesejahteraan dan Sosial Budaya Masyarakat Lokal, Jakarta: Departemen Sains Komunikasi dan Pengembangan Masyarakat

Winarno, Budi, 2014. Kebijakan Publik (Teori, Proses, Dan Studi Kasus) Yogyakarta: CAPS.

Wirawan, Gede Putu Surya. 2009. Pengembangan Daya Tarik Wisata Bahari Secara Berkelanjutan di Nusa Lembongan Kabupaten Klungkung, Denpasar: Program Pascasarjana Universitas Udayana .

Wirawan, Gede Putu Surya. 2009. Pengembangan Daya Tarik Wisata Bahari Secara Berkelanjutan di Nusa Lembongan Kabupaten Klungkung, Denpasar: Program Pascasarjana Universitas Udayana .

Profil Desa. 200915. Profil Desa Sanur Kauh Kecamaan Denpasar Selatan Kota Denpasar Tahun 2015r: Program Pascasarjana Universitas Udayana . Profil Desa, Denpasar

Balai Lingkungan Hidup. 2016. Pengellaan Wilayah Pesisir Kota Denpasar, Bali Indonesia: Pemerintah Kota Denpasar

Wirawan, Gede Putu Surya. 2009. Pengembangan Daya Tarik Wisata Bahari Secara Berkelanjutan di Nusa Lembongan Kabupaten Klungkung, Denpasar: Program Pascasarjana Universitas Udayana . 